\title{
GOD, KING, FATHERLAND - AND ELECTIONS. THE INTRODUCTION OF THE MUNICIPAL SELF-GOVERNMENT IN PRUSSIA IN 1808 SEEN THROUGH THE PERSPECTIVE OF THE PROTESTANT SERMON
}

\author{
Dmitrii V. Sterkhov \\ Pirogov Russian National Research Medical University, Moscow, Russian Federation
}

\begin{abstract}
Introduction. The current study focuses on a number of sermons preached by the Prussian Protestant ministers on the occasion of the first municipal elections in Prussia in 1809-1810. The paper seeks to show that the Prussian Protestant clergy supported the introduction of the municipal self-government and inspired the population to take part in elections. Methods. The paper presents a case study dealing with the problem of the interaction between religious and political spheres in the early nineteenth century. This gives rise to the interdisciplinary approach adoptedin the current study. Analysis. Prussian Protestant preachers combined religious symbols with liberal vocabulary advancing the thesis that a good Christian is an honest citizen. The sermons abounded in such terms as "public spirit", "civic responsibility" or "love of the Fatherland". God was directly involved in the earthly politics since the municipal self-government was regarded as a divine gift from heaven. The Holy Spirit was thought to be present at municipal elections watching over the minds and the hearts of citizens. Prussian Monarch Frederick William III was stylized in the sermons as a typical "citizen King" who respected the rights of his subjects. The Prussian Kingdom was imagined as a big family with the King as the Father of the nation, the Prussians being his grown-up children. The introduction of the municipal self-government was thus described as "coming of age" of the Prussian people. Conclusion. The case study of the Protestant clergy supporting the liberal reforms conducted by the Prussian government proves that modernization did not always mean secularization.

Key words: Stein-Hardenberg reforms, modernization, secularization, sermon, Municipal Ordinance of 1808 , Frederick William III, religion and politics, Prussian Reform Movement.
\end{abstract}

Citation. Sterkhov D.V. God, King, Fatherland - And Elections. The Introduction of the Municipal SelfGovernment in Prussia in 1808 Seen Through the Perspective of the Protestant Sermon. Vestnik Volgogradskogo gosudarstvennogo universiteta. Seriya 4. Istoriya. Regionovedenie. Mezhdunarodnye otnosheniya [Science Journal of Volgograd State University. History. Area Studies. International Relations], 2020, vol. 25, no. 5, pp. 20-31. (in Russian). DOI: https://doi.org/10.15688/jvolsu4.2020.5.2

\section{БОГ, КОРОЛЬ, ОТЕЧЕСТВО - И ВЫБОРЫ. РЕФОРМА ГОРОДСКОГО САМОУПРАВЛЕНИЯ 1808 г. В ОТРАЖЕНИИ ПРУССКОЙ ПРОТЕСТАНТСКОЙ ПРОПОВЕДИ}

\footnotetext{
Дмитрий Владимирович Стерхов Российский национальный исследовательский медицинский университет им. Н.И. Пирогова, г. Москва, Российская Федерация
} 
озные символы и либеральную лексику, священники выдвигали тезис о том, что истинный христианин должен быть честным гражданином, добросовестно исполняющим свои обязанности перед обществом и государством. Городское самоуправление преподносилось в проповедях как дар небес, тем самым Бог напрямую вмешивался в земную политику. Прусский монарх Фридрих Вильгельм III изображался духовенством как «король-гражданин», который правит в соответствии с законом и уважает свободы своих подданных. Само прусское королевство воображалось как одна большая семья во главе с королем - отцом нации. Пруссаки выступали в качестве детей, достигших совершеннолетия, в связи с чем отец-король даровал им право самоуправления. Пример Пруссии, где либеральные реформы активно поддерживались протестантской церковью, свидетельствует о том, что процесс модернизации, имевший место в Европе в ХІХ в., не всегда означал секуляризацию.

Ключевые слова: реформы Штайна-Гарденберга, модернизация, секуляризация, проповедь, Городское уложение 1808 года, Фридрих Вильгельм III, религия и политика, прусские реформы.

Цитирование. Стерхов Д. В. Бог, король, отечество - и выборы. Реформа городского самоуправления 1808 г. в отражении прусской протестантской проповеди // Вестник Волгоградского государственного университета. Серия 4, История. Регионоведение. Международные отношения. - 2020. - Т. 25, № 5. - С. 20-31. DOI: https://doi.org/10.15688/jvolsu4.2020.5.2

Введение. Катастрофическое поражение, понесенное Пруссией в войне против Франции 1806-1807 гг., стало катализатором политики либеральных преобразований, связанных в первую очередь с именами великих прусских реформаторов барона Генриха Фридриха Карла фом унд цум Штайна и Карла Августа фон Гарденберга. Одной из наиболее известных стала реформа городского самоуправления, утвержденная королевским указом 19 ноября 1808 года. В основе городской реформы, автором которой стал ближайший сподвижник Штайна, кенигсбергский чиновник Иоганн Готтфрид Фрай, лежала идея самоуправления: отныне практически все вопросы муниципальной жизни должны были решаться самими жителями города, чьи интересы представляло выборное собрание депутатов (Stadtverordnetenversammlung). Прогрессивный характер реформы заключался в первую очередь в том, что депутаты избирались не по сословиям, цехам или гильдиям, а от всей городской общины в целом. Кроме того, отменялись права и привилегии отдельных городов, в Пруссии стала складываться унифицированная муниципальная система [16, р. 38-40].

Несмотря на свой прогрессивный характер, реформа имела существенные недостатки. Так, избирательные права предоставлялись не автоматически, а были ограничены цензом оседлости, а также образовательным и имущественным цензами. Женщины, дети, слуги, подмастерья, гарнизонные солдаты, лица без определенного места жительства и постоян- ного заработка, по сути, были исключены из гражданской общности. Круг лиц, приобретавших гражданские права, был крайне ограничен и составлял не более 8-9 \% городского населения. В эту категорию попадали преимущественно зажиточные домохозяева, ремесленники, купцы, интеллигенция и чиновники. Однако даже те, кто получал гражданские права, не спешили ими воспользоваться, так как большая часть городского населения не понимала смысла реформы и рассматривала самоуправление как тяжкую повинность, от которой следовало всячески уклоняться. Барон фом унд цум Штайн предвидел подобное развитие событий, поэтому еще в процессе разработки проекта настоял на том, чтобы привлечь протестантское духовенство к процессу популяризации реформы. По идее министра, муниципальным выборам должны были предшествовать праздничные богослужения, сопровождаемые чтением проповедей [8, p. 69].

В данной работе предпринята попытка проанализировать значение религиозной аргументации в процессе популяризации реформы городского самоуправления прусским протестантским духовенством. Для достижения обозначенной цели поставлены следующие задачи:

1. Определить, каким образом прусские пасторы комбинировали христианские символы и понятия с либеральной терминологией.

2. Установить, какую роль в политической жизни пруссаков духовенство отводило Богу. 
3. Выяснить, какую роль в процессе подготовки реформы пасторы отводили прусскому монарху Фридриху Вильгельму III и с помощью каких средств создавали образ «короля-гражданина».

4. Оценить значение терминологии семейных отношений, с помощью которой прусские проповедники обосновывали необходимость реформы городского самоуправления.

Актуальность работы объясняется возросшим с начала 2000-х гг. интересом историков и социологов к проблеме взаимосвязи религии и государства, а также спорами, ведущимися вокруг теории модернизации и секуляризации, согласно которой складывание современного общества шло параллельно с процессом обмирщения сознания и культуры. Теория модернизации имела огромное влияние на развитие социально-гуманитарных наук во второй половине XX в., однако сегодня она подвергается резкой критике многими исследователями [6, p. 12-13]. Пример Пруссии призван показать, что модернизация не всегда означает секуляризацию.

Методы и материалы. В основе статьи лежит метод ситуационного анализа, позволяющий подробно изучить конкретную историческую ситуацию для понимания более глобального исторического процесса. Объектом исследования является взаимодействие религиозной и политической сфер в начале XIX в., в связи с чем применяется междисциплинарный анализ. Предмет исследования взгляды прусского протестантского духовенства на городскую реформу 1808 г., высказанные ими в прочитанных и опубликованных проповедях. Источниковую базу исследования составляют 19 проповедей, прочитанных по случаю избрания или приведения к присяге городских представителей, также статья опирается на историографию проблемы введения городского самоуправления в Пруссии в 1808 1809 годах.

В научной литературе городская реформа 1808 г. рассматривается как важный шаг на пути к демократии и гражданскому обществу [2, p. 20]. Цель реформы, по мнению некоторых исследователей, заключалась в политическом воспитании нации, пробуждении духа общности, патриотизма и гражданской ответственности $[1$, p. 70$]$. Известный исто- рик Томас Ниппердай трактовал городскую реформу как первый шаг к эмансипации гражданского общества [16, p. 39]. Вместе с тем некоторые историки указывают на недостатки реформы и ее низкую популярность среди населения. Так, по мнению Бернда фон Мюнхов-Поля, население Пруссии совсем не было готово к самоуправлению [12, р. 124-127]. Историк Илья Мик высказывал мнение, что закон о городском самоуправлении был больше консервативным, чем либеральным [11, p. 70-71]. Мало кто из авторов, занимавшихся изучением реформы, обращался к вопросу о том, с помощью каких средств прусское правительство пыталось популяризовать реформу среди населения и какая роль в этом процессе отводилась религии.

Примерно в середине XVIII в. в Пруссии сложилась традиция издавать проповеди, рассчитанные на массового читателя. Важную роль сыграли события Семилетней войны (1756-1763 гг.), так как именно в этот период в проповедях стали затрагиваться общественно-политические вопросы. В эпоху Наполеоновских войн проповедь продолжала оставаться одним из наиболее популярных жанров повседневной литературы, что объяснялось несколькими причинами. Во-первых, ввиду отсутствия современных средств массовой информации в XVIII-XIX вв. основным способом получения и обмена новостями, в том числе и политического характера, служило посещение церковного богослужения. Проповедь обладала несомненным преимуществом по сравнению с памфлетом или газетной статьей, так как она не просто печаталась, но в первую очередь произносилась вслух, охватывая тем самым и неграмотное население [17, p. XIII-XIV]. Во-вторых, еще в XVII в. в Пруссии сложилась система бюрократического управления церковью (landesherrliches Kirchenregiment), в рамках которой священник, по сути, являлся государственным чиновником, которого назначал особый орган по управлению делами церкви (консистория). Круг обязанностей прусского пастора не ограничивался только заботой о душах прихожан, духовенству приписывались новые функции, как, например, перепись населения, составление списков рекрутов для армии, зачитывание с церковных амвонов пра- 
вительственных постановлений и прокламаций, организация религиозно-патриотических праздников и т. д. [9, p. 99-100]. Выступая от имени государства, прусский священник играл роль посредника между властью и обществом. И, конечно же, проповедник мог внушать своим прихожанам те идеи, которые были выгодны власти. Соответственно, проповедь отчасти служила инструментом государственной пропаганды. В Пруссии механизм мобилизации духовенства в интересах государства был хорошо отлажен и активно применялся в эпоху Наполеоновских войн.

В этой связи не вызывает удивления тот факт, что введение городского самоуправления также сопровождалось чтением и публикацией значительного числа проповедей, прочитанных прусскими протестантскими пасторами по этому поводу в 1809-1810 годах. Стоит отметить, что не только проповедники из крупных городов, таких как Берлин или Кенигсберг, стремились отдать в печать свои проповеди, но также пасторы из маленьких общин находили возможность донести свои идеи до как можно более широкого круга читателей. До нас дошли проповеди таких крупных теологов, как Фридрих Шлейермахер (Берлин) или Рулеманн Фридрих Эйлерт (Потсдам), но также и малоизвестных проповедников, к числу которых относятся пасторы Вильгельм Вегенер (Цюллихау, Бранденбург), Иоганн Нойманн (Альтландсберг, Бранденбург), Томас Тиде (Райхенбах, Силезия), Иоганн Трист (Шеттин, Померания), суперинтендант Юстус Фердинанд Шульце (Фюрстенвальде, Бранденбург). Проповеди прусских пасторов, прочитанные по поводу введения городского самоуправления, дают нам представление о том, с помощью каких аргументов священники пытались убедить население в разумности и целесообразности нового закона.

Анализ. Первая задача, которая стояла перед пасторами, заключалась в том, чтобы объяснить смысл абсолютно новой и непонятной для многих процедуры выборов. Не случайно некоторые проповеди начинались с того, что священник подробно разъяснял техническую сторону королевского указа. Многие пасторы отмечали нежелание жителей являться на выборы ввиду страха перед непривычным мероприятием [29, р. 58] или слишком сильной привязанностью к старым порядкам и предрассудкам [18, р. 12], в связи с чем и возникала необходимость убедить паству в правильности нового городского уложения с религиозной точки зрения. При этом стоит отметить тот факт, что пасторы стремились соединить религиозные понятия и христианские символы с либеральной лексикой, свойственной высшему прусскому чиновничеству. Такие термины, как «дух общности» (Gemeingeist), «гражданственность» (Bürgersinn), «любовь к отечеству» (Vaterlandsliebe), «гражданская ответственность» (bürgerliches Verantwortungsgefühl), «гражданские свободы» (bürgerliche Freiheiten), которыми оперировали авторы закона о городском самоуправлении, активно использовались проповедниками в их речах. Проповеди пестрят такими понятиями, как «гражданин» (Bürger), «гражданский» (bürgerlich) и производными от них. Сам день выборов предстает в проповедях как религиозный и гражданский праздник одновременно [14, p. 57]. Это обстоятельство говорит о том, что новые либеральные понятия достаточно прочно вошли в лексикон прусского протестантского духовенства.

Понятие «гражданин» проповедники тесно связывали с представлениями о правах, которыми он должен обладать. Так, Иоганн Трист из померанского Штеттина считал прежнее, устаревшее значение слова «гражданин», под которым понимался «не более чем житель города, который постоянно проживает в нем, занимается ремеслом, платит налоги и несет всевозможные повинности», слишком узким и ограниченным. Тот, кто не имеет прав, утверждал священник, не может именоваться настоящим гражданином. Новое городское уложение как раз было призвано восстановить справедливость: «Теперь больше так не должно быть. Настоящие, полные права будут возвращены гражданину» [27, p. 910]. На то же указывал и силезский проповедник Томас Тиде, который полагал, что именно наличие прав и свобод делает из подданного ответственного и самостоятельного гражданина [25, p. 3]. Однако понятие «гражданство» включало в себя и наличие обязанностей перед государством, нести которые помогала христианская этика. Проповедники апеллировали к традиционному представлению о любой власти как данной свыше Богом, так, пот- 
сдамский пастор Рулеманн Эйлерт напоминал в одной из своих проповедей: «Власть дана Богом, а значит, что каждый является подданным. Кто противится своей власти, тот противится божественному порядку, а значит, его ждет суровое наказание» [4, p. 409]. Однако отличие подобного отношения к власти от раболепного повиновения проповедник видел в том, что настоящий гражданин повинуется власти из убеждения и полного осознания своей гражданской ответственности, в то время как раб пытается избежать наказания. Та же мысль звучит в проповеди Фридриха Шлейермахера, который делал прямое различие между рабским повиновением власти изза боязни наказания и осознанным повиновением законам. Именно в добровольном подчинении законам Шлейермахер видел истинную свободу гражданина $[18$, p. 6]. Суть нового гражданского состояния заключалась в балансе свободы и ответственности перед обществом. В этом же духе высказывался проповедник Нойманн, отвечая на вопрос, что такое гражданский порядок: «Под таким порядком мы понимаем гражданское состояние, согласно которому благополучие города достигается благодаря принятым сверху и согласованным с избранными и полномочными гражданами законам. Ошибается тот, кто полагает, что новое городское уложение предоставляет такие неограниченные свободы, согласно которым и начальники, и подчиненные могли бы действовать по своему усмотрению, не неся ответственности перед государственными органами власти» [13, p. 91].

Таким образом, религиозная мораль и христианская этика должны были разумно ограничивать свободу гражданина и напоминать ему об обязанностях перед обществом и государством. В связи с этим прусские священники выдвигали тезис о том, что истинный гражданин одновременно является истинным христианином. Религиозные и гражданские ценности сливались воедино. Проповедник Пальмье завершал свою проповедь молитвой, которая заканчивалась такими словами: «Давайте же мы будем как истинными христианами, так и хорошими гражданами; как приверженцы религии любви давайте же думать не только о себе, но и о других; давайте же мы соединим законы государства с зако- нами нравственности и добродетели» [30, p. 70-71]. Сходство между гражданином и верующим находил и пастор Трист: точно так же, как и истинный христианин, истинный гражданин думает о благе общества, неуклонно следует законам, помогает нуждающимся и страждущим, а в случае необходимости жертвует самым ценным ради спасения большинства. Как настоящий верующий, настоящий гражданин «не думает о своем имуществе, о своем здоровье, о своем домашнем счастье, об опасностях, которые угрожают его жизни, если речь идет об исполнении своего гражданского долга» $[27$, p. 24]. О единстве гражданских и христианских обязанностей проповедовал и пастор Нойманн: «Благополучие всех государств зависит только лишь от того, насколько граждане руководствуются в своих поступках религиозными принципами. Также и наш город можно будет назвать благочестивым и праведным, если его фундаментом станет религия. Также и новое городское уложение послужит счастью нашего города, если мы и поступками, и мыслями будем доказывать нашу приверженность религии, если власть предержащие будут искать не человеческой благосклонности, а божьей милости, если жители нашего города будут добровольно следовать правительственным законам из любви к Богу» [13, p. 99-100]. Дабы сделать свою аргументацию еще более убедительной, многие проповедники прибегали к образам Иисуса Христа и апостола Павла как тех личностей, которые успешно сочетали в себе истинную религиозность и гражданскую ответственность. Так, в одной из проповедей, прочитанных еще в 1806 г., накануне войны с Францией, Фридрих Шлейермахер отмечал: «Прежде чем принести свет своего учения другим народам, Христос хотел предложить его сначала своим согражданам. Неустанно говорил он своему народу о том, что может послужить для его мира и процветания, даже несмотря на то, что в конце концов он мог лишь только плакать о несчастной судьбе своих соотечественников. Апостол Павел же, даже после того, как этот самый народ отверг единственный путь к спасению, продолжал славиться своим неугасающим патриотизмом, и мы знаем, какую боль он испытывал за своих сограждан. Наше призвание обя- 
зывает нас во всем походить на эти примеры истинной веры» [20, p. 233]. Если основоположники христианской веры отличались гражданской сознательностью и ответственностью, то это же самое предписывалось и их последователям.

Являются ли гражданские права и обязанности продуктом человеческой деятельности? Прусские проповедники однозначно отвечали на этот вопрос: гражданские свободы имеют божественное происхождение. Настоящим автором реформы городского самоуправления в проповедях предстает сам Бог, который, выступая в качестве самостоятельно действующей личности, напрямую вмешивается в земную политику. Так, суперинтендант Шульце из городка Фюрстенвальде утверждал, что новое городское уложение является подарком небес, который Господь ниспосылает пруссакам в знак своего расположения к ним: «Примите этот дар, который шлют нам небеса от имени Бога. Будем тверды в нашем намерении чтить этот подарок как священную реликвию, благодаря которой мы сможем достичь совершенства, к которому она позволит нам возвыситься» [21, p. 8081]. В этом был убежден и Иоганн Трист, который также рассматривал городское самоуправление как акт божьей милости [27, p. 7].

Если введение городского самоуправления преподносилось как результат божественной воли, то, конечно же, Бог должен был внимательно следить за тем, как его воля исполняется. Совсем не случайно выборы организовывались в виде праздничных богослужений и проходили в церквях - Всевышний незримо присутствовал во время процедуры избрания городских представителей, внимательно наблюдая за чувствами и думами избирателей. Проповедники, конечно же, напоминали своим слушателям о том, что они должны голосовать честно и непредвзято, ибо ответственность за свой выбор они несут перед самим Богом. Пастор Нойманн внушал горожанам накануне выборов: «Вы должны выбирать не ваших друзей, не ваших родственников, не ваших помощников в трудную минуту, не вашего заимодавца, но вы должны выбирать людей благоразумных и понимающих, отличающихся безупречной репутацией, неподкупной верностью, решительностью и стойкостью в час опасности, не взирая при этом на свою личную выгоду и не надеясь на благодарность в ответ» $[15$, p. 6]. В случае же нечестного, предвзятого выбора на жителей города должен был вновь обрушиться божий гнев, о чем проповедники также неустанно напоминали своим согражданам, как, например, суперинтендант Шульце, который утверждал: «Горе тому, кто сам хорошо видит и понимает, что своим выбором он творит несправедливость, что он открывает двери нашего города глупости, грубости и злу, которые принесут нашему городу и нашей общине несчастье и горе, стыд и позор, ибо они обрушатся на его дом, на его семью, на его детей. Горе тому, кто видит и понимает, что своим несправедливым выбором он наносит нашему городу глубокие раны, которые будут кровоточить даже тогда, когда он сам уже умрет. Сможет ли такой человек жить в мире с Богом и собственной совестью? Не будет ли он упрекать и проклинать себя за свой неправедный выбор? Не будет ли мучить его совесть на смертном одре? Не будет ли он терзаться чувством сожаления и раскаяния на Страшном суде?» [22, р. 66-67].

Приведение к присяге избранных городских представителей и членов нового магистрата, точно так же, как выборы, проводилось в церкви и сопровождалось чтением специальной проповеди. Вновь Бог незримо присутствовал при этой процедуре, выступая свидетелем приносимой клятвы, о чем, к примеру, напоминали собранию городских представителей пасторы Вегенер и Шульце, последний, обращаясь к бургомистру и членам городского совета, проповедовал так: «Вы приносите священную присягу, верность которой вы должны хранить всегда. Всевышний выступает сегодня в качестве свидетеля вашей клятвы. Он судит справедливо, и однажды он потребует от вас отчета, никогда вы не сможете избежать его всемогущей власти. В ваш последний час у вас не останется ничего, кроме Бога и вашей совести, и если вы хотите, чтобы ваш последний час прошел в мире и блаженстве, о, отцы этого города, я призываю вас именем Бога и короля, именем Отечества и этого города, я призываю вас, во имя всего, что вам дорого, во имя вашего душевного спокойствия, во имя вашего душевного спа- 
сения: принесите истинную, верную клятву, исполните все, что вы пообещали!» [21, p. 87]. Подобные увещевания, безусловно, служили в качестве своеобразной дисциплины как для тех, кто избирает, так и для тех, кого избирают. Городские жители и избранная ими городская администрация несли коллективную ответственность перед Богом за свои действия.

Несмотря на то что Бог объявлялся пасторами как истинный учредитель городского самоуправления, действовал он все же не напрямую, а через своего представителя прусского короля. Примечателен тот факт, что в проповедях ни разу не упоминаются действительные разработчики городской реформы, в связи с чем у слушателей и читателей должно было сложиться впечатление, что инициатива исходила напрямую от монарха, хотя еще известный немецкий историк Макс Леманн в статье 1898 г. указывал на то обстоятельство, что роль Фридриха Вильгельма III, по сути, ограничилась только тем, что он поставил подпись под соответствующим указом. Реформа готовилась и обсуждалась исключительно представителями высшей бюрократии, словно никакого монарха в Пруссии и не существовало $[10$, p. 512]. Совсем обратную картину можно наблюдать в проповедях: именно король предстает в них как единственный автор реформы, именно он дарует городское самоуправление жителям Пруссии, а не его министры. Очевиден тот факт, что проповеди преследовали цель восстановить пошатнувшийся авторитет монарха, подорванный поражением 1806 г. и бегством из столицы в далекую Восточную Пруссию. С другой стороны, проповедники продолжали апеллировать к традиционной концепции монаршей власти милостью божьей, которая и в начале XIX в. продолжала оставаться популярной среди населения.

Тем не менее проповедники дополняли образ Фридриха Вильгельма III новыми чертами, которые выходили за пределы традиционной концепции правителя милостью божьей. В проповедях прусский монарх предстает как «король-гражданин» (Bürgerkönig), который близок к своему народу и практически ничем не отличается от своих граждан. В особенности пасторы выделяли нелюбовь Фридриха Вильгельма III к помпезности и роско- ши. Простота и скромность придворной жизни, отсутствие пышности и лоска, характерных для абсолютных монархов, всячески подчеркивались проповедниками. Так, в одной из проповедей можно прочесть: «Наш добрый отец Отечества презирает всякую роскошь, которая слепит глаза, но слишком дорого обходится подданным. Он избегает любого расточительства, которое могло бы осветить его блеском и глянцем, но которое точно так же могло бы ввергнуть в нищету большую часть народа» [3, p. 43]. Скромный образ жизни, лишенный неестественной вычурности и излишней изысканности, органично сочетался с желанием монарха избегать публичности и искать личного счастья в лоне своей семьи. Однако Фридрих Вильгельм III представал в качестве «короля-гражданина» не только потому, что он являлся образцом бюргерских добродетелей - в проповедях вполне отчетливо звучит и эгалитарный подтекст. Проповедники убеждали свою паству в том, что прусский монарх правит не как тиран, чьей воле все должны безоговорочно подчиняться, но как справедливый государь, который рассматривает своих подданных как равноправных граждан. По мнению проповедника Триста, Фридрих Вильгельм III ценил права и свободы подданных выше своих собственных прав и привилегий [27, p. 37], в то время как силезский пастор Самуэль Чеггей указывал на то обстоятельство, что король правит Пруссией не по своему усмотрению, а в соответствии с «законом и правом» [28, р. 92]. Фридрих Шлейермахер прослеживал традицию прусских королей рассматривать «всех граждан равными перед законом» еще со времен Фридриха II Великого [19, р. 367], в то время как Томас Тиде превозносил заслуги Фридриха Вильгельма III даже выше всех достижений его прославленного двоюродного деда $[26$, p. 106]. В одной из проповедей Тиде назвал Фридриха Вильгельма III «первым гражданином государства» [25, p. 3], подчеркивая стремление монарха уважать права подданных.

В 1989 г. немецкий историк Томас Штамм-Кульманн опубликовал статью под названием «Был ли Фридрих Вильгельм III королем-буржуа?». Исследователь пришел к выводу, что, несмотря на свою тягу к бюр- 
герскому образу жизни, «буржуазным» королем в эгалитарном понимании этого слова Фридрих Вильгельм III, конечно же, не был, оставаясь на протяжении всего своего правления абсолютным монархом [24, p. 458]. Вероятно, прусский король действительно не являлся сторонником равноправия, но именно такой образ создавался в умах пруссаков посредством повседневной литературы, в том числе и протестантской проповеди. Как известно, одним из первых титул «короля-буржуа» получил французский монарх Луи-Филипп Орлеанский, однако задолго до него такого звания был удостоен Фридрих Вильгельм III, и протестантские проповедники внесли немалый вклад в создание образа прусского «короля-гражданина», который при этом оставался традиционным правителем милостью Божьей. Будучи проводником Божьей воли, Фридрих Вильгельм III, по мнению духовенства, заключал с Пруссией новый, «гражданский союз» (Bürgerbund), обещая своим подданным отныне уважать их права и свободы. В этой аналогии очевиден намек на Новый Завет. Так, некоторые пасторы говорили о «старом гражданском состоянии» (altes Bürgertum), когда жители прусских городов не имели права самоуправления, и «новом гражданском состоянии» (neues Bürgertum), когда они такое право, наконец, получали [14, p. 57]. Точно так же, как Иисус заключил новый завет со всем человечеством, так же прусский король заключил новый, «гражданский» завет со своим народом или - другая, не менее популярная метафора - возложил на голову своей страны новую, «гражданскую корону» $[26$, р. 106]. Христианские мотивы и символы органично сочетались с либеральными и эгалитарными идеями, что прекрасно иллюстрирует создаваемый в проповедях образ прусского короля.

Цели популяризации реформ служила не только религиозная тематика, но и терминология семейных отношений. Немецкая исследовательница Карен Хагеманн указывает на то, что в начале XIX в. нации в монархических государствах воображались как большие семьи, во главе которых стояли монарх, представляемый как отец своего народа, и его супруга - мать Отечества [7, р. 589]. Именно такую ситуацию можно наблюдать в Прус- сии эпохи Наполеоновских войн, и протестантская проповедь служила одним из основных средств создания подобной конструкции. Практически на каждой странице каждой проповеди Фридрих Вильгельм III именовался «отцом страны» (Landesvater). Прусская нация воображалась как одна большая семья. Не случайно потсдамский проповедник Рулеманн Эйлерт начинал свою проповедь, посвященную возвращению короля, его семьи и его правительства в Берлин в конце 1809 г., с сравнения: «Большая, многочисленная семья была разлучена со своим отцом, к которому она испытывает почтение и сердечную любовь» $[5$, p. 47]. В проповеди Эйлерта четко звучит мотив сиротства: спасаясь бегством от наступающих французских войск, прусский король был вынужден покинуть свою резиденцию и бежать на самую окраину своего государства - в Восточную Пруссию, его дети (подданные) остались без отца. Цель короля как отца народа, соответственно, заключалась в том, чтобы утешить своих детей и облегчить их страдания, чего можно было достичь с помощью полезных для общества и государства преобразований. Реформа городского самоуправления рассматривалась пасторами как попытка любящего отца облегчить тяжелую судьбу своих детей. В этом духе проповедовал в 1809 г. пастор Томас Тиде жителям силезского города Райхенбах: «О, почувствуйте и поймите вы все, что для вас сегодня делает Фридрих Вильгельм Третий, ваш король и ваш отец! Он желает осушить ваши слезы, унять ваши вздохи, залечить ваши раны! То, что он дарует вам сегодня, позволит вам позабыть о вашей боли!» [26, p. 105]. По мнению пастора Самуэля Чеггея, с помощью реформ прусский король желает добиться только одного - «счастья для своих детей» $[28$, p. 82]. Реформа городского самоуправления, таким образом, являлась даром любящего отца своим детям.

В самом факте репрезентации монарха как «отца Отечества», безусловно, не было ничего необычного, это был традиционный способ легитимации королевской власти, однако и в этот конструкт прусские пасторы привносили нечто новое. В проповедях отчетливо звучит еще один мотив, а именно взросления, совершеннолетия. До введения реформы 
пруссаки находились в состоянии «несовершеннолетия» (Minderjährigkeit), они не умели принимать самостоятельные решения, поэтому король-отец управлял от их имени. Пруссия в данном контексте предстает как взрослеющий ребенок, переходящий из стадии юности в стадию зрелости. Пастор Томас Тиде отмечал: «Подобное положение дел являлось противоестественным, сын и наследник стал тяготиться излишней отеческой опекой, особенно в последнее время, когда становилось все более очевидным, что период несовершеннолетия уже давно прошел» [26, p. 107]. В этом же духе проповедовал жителям города Фюрстенвальде суперинтендант Шульце: «Счастлив тот сын, чей отец посчитал его достаточно благонадежным и объявил зрелым, способным управлять самим собой и своими делами... Также и отец своего народа, наш король, объявил вас, жители этого города, как и всех жителей страны, совершеннолетними. Он даровал вам права и свободы, которые вступают в силу в связи с новым городским самоуправлением» [23, p. 63]. Отныне пруссаки получили возможность принимать решения, касающиеся жизни своего государства, именно так полагал пастор Пальмье, который описывал выборы городского магистрата следующим образом: «Мы рассматриваем себя как большую семью, которая собирается вместе для того, чтобы совместно обсудить общее благо всего дома» [30, p. 67]. Состояние совершеннолетия предусматривало, однако, не только наличие прав, но и обязанностей, которые должен исполнять каждый гражданин. В проповеди, посвященной разъяснению того, что такое гражданский дух, померанский пастор Иоганн Трист утверждал: «Настоящий гражданин безропотно несет все тяготы, которые на него возлагает его Отечество, он несет их как член большой семьи, вместе с которой он делит и радость, и горе» [27, p. 23]. По мнению Фридриха Шлейермахера, только зрелый, самостоятельный и ответственный человек может быть настоящим гражданином и верным патриотом, подчиняющийся власти не из страха перед наказанием, как ребенок, но из убеждения. А быть настоящим гражданином в трактовке Шлейермахера одновременно означало быть истинным христианином [18, p. 12-13].
Заключение. Христианская проповедь совсем не случайно была избрана прусскими реформаторами для популяризации реформы городского самоуправления. Протестантские пасторы умело комбинировали религиозные понятия и либеральные идеи, которые власть хотела внушить обществу, этот язык был прост и понятен большинству населения. Ответственность за соблюдение своих прав и обязанностей граждане несли перед Богом, а образ «короля-гражданина» был призван укрепить лояльность подданных к правящей династии. Этой же цели служил образ Пруссии как большой семьи, в которой пруссаки выступали в качестве совершеннолетних детей, ответственных за судьбу государства. Реформа городского самоуправления, несмотря на все ее недостатки, безусловно, была прогрессивной, и тот факт, что протестантское духовенство поддержало ее в своих проповедях, говорит об одном: модернизация не всегда означает секуляризацию. Переход от традиционного общества к современному, который можно наблюдать в XIX в., зачастую осуществлялся как раз с помощью традиционных методов и традиционной идеологии. Пример Пруссии эпохи реформ, где либеральные идеи были тесно связаны с христианским мировоззрением, свидетельствует о том, что религия и церковь могли оказывать существенное влияние на складывание современного общества и государства.

\section{СПИСОК ЛИТЕРАТУРЫ}

1. Botzenhart, M. Reform, Restauration, Krise. Deutschland 1789-1847 / M. Botzenhart. - Frankfrurtam-Main : Suhrkamp Verlag, 1985. - 171 p.

2. Cancik, P. "Einer wirksamern Theilnahme der Bürgerschaft..." Partizipationskonzepte zu Beginn des 19. Jahrhunderts / P. Cancik // Die Stadtverordnetenversammlung von Potsdam im Wandel der Zeit / eds.: C. Büchner, A. Musil. - Potsdam : Universitätsverlag Potsdam, 2010. - P. 19-37.

3. Dapp, R. Am 1. Adventssonntage 1808 / R. Dapp // Gemeinnütziges Magazin für Prediger auf dem Lande und in kleinen Städten. - 1809. - № 3 (3). P. 41-48.

4. Eylert, R. F. Ein religiöser Sinn muß zu Hülfe kommen, wenn den Gesetzen des Staates von den Unterthanen ein volles Genüge geschehen soll / R. F. Eylert // Die Gedächtnißfeyer der verewigten 
Königin Luise von Preußen. - Berlin : Georg Decker, 1812. - P. 397-416.

5. Eylert, R. F. Wie wollen wir unseren König empfangen? / R. F. Eylert // Die weise Benutzung des Unglücks. Predigten, gehalten im Jahre 1809 und 1810. Berlin : Carl Friedrich Amelang, 1810. - P. 47-62.

6. Fox, J. A World Survey of Religion and the State / J. Fox. - Cambridge : Cambridge University Press, 2008. - 206 p. - DOI: https://doi.org/10.1017/ CBO9780511993039.

7. Hagemann, K. Nation, Krieg und Geschlechterordnung. Zum kulturellen und politischen Diskurs in der Zeit der antinapoleonischen Erhebung Preußens 1805-1815 / K. Hagemann // Geschichte und Gesellschaft. Zeitschrift für historische Sozialwissenschaft. - 1996. - № 22 (4). - P. 562-591.

8. Heger, A. Evangelische Verkündigung und deutsches Nationalbewusstsein. Zur Geschichte der Predigt von 1806-1848 / A. Heger. - Berlin : Junker und Dünnhaupt Verlag, 1939. - 280 p.

9. Hintze, O. Die Epochen des evangelischen Kirchenregiments in Preußen / O. Hintze // Historische Zeitschrift. - 1906. - № 97 (1). - P. 67-118.

10. Lehmann, M. Der Ursprung der Städteordnung von 1808 / M. Lehmann // Preußische Jahrbücher. - 1898. - № 93. - P. 471-514.

11. Mieck, I. Die verschlungenen Wege der Städtereform in Preußen (1806-1856) / I. Mieck // Sösemann B. Gemeingeist und Bürgersinn. Die preußischen Reformen. - Berlin : Duncker \& Humblot, 1993. - P. 53-83.

12. Münchow-Pohl, B. Zwischen Reform und Krieg. Untersuchungen zur Bewußtseinlage in Preußen 1809-1812 / B. Münchow-Pohl. - Göttingen : Vandenhoeck \& Ruprecht, 1987. - 479 p.

13. Neumann, J. Predigt am 23. Jul. 1809. vor der feierlichen Einsetzung des neuen Magistrats zu AltLandsberg / J. Neumann // Gemeinnütziges Magazin für Prediger auf dem Lande und in kleinen Städten. 1810. - №4 (2). - P. 88-103.

14. Neumann, J. Predigt bei wiederholter Wahl der Stadtverordneten in Alt-Landsberg 1810 / J. Neumann // Magazin für Prediger auf dem Lande und in kleinen Städten. - 1811. - № 5 (3). - P. 57-67.

15. Neumann, J. Predigt bey Gelegenheit der Allerhöchst anbefohlenen neuen Städteordnung vor der Wahl der Stadtverordneten in Alt-Landsberg gehalten am 20sten März 1809 / J. Neumann. - Berlin : Dieterici, 1809. - $16 \mathrm{p}$.

16. Nipperdey, T. Deutsche Geschichte 1800 1866. Bürgerwelt und starker Staat / T. Nipperdey. München : Verlag C. H. Beck, 1983. - 838 p.

17. Oberschelp, R. Politische Predigten 17271866. Niedersächsische Beispiele aus Krieg und Frieden / R. Oberschelp. - Hildesheim : Verlag August Lax, 1985. - 224p.
18. Schleiermacher, F. Ueber das rechte Verhältniß des Christen zu seiner Obrigkeit. Im Januar 1809 / F. Schleiermacher // Friedrich Schleiermacher's sämmtliche Werke. Zweite Abtheilung. Predigten. Band 4. - Berlin : Verlag G. Reimer, 1835. - P. 1-13.

19. Schleiermacher, F. Ueber die rechte Verehrung gegen das einheimische große aus einer früheren Zeit. Am vierundzwanzigsten Jenner 1808/F. Schleiermacher // Friedrich Schleiermacher's sämmtliche Werke. Zweite Abtheilung. Predigten. Band 1.-Berlin : Verlag G. Reimer, 1834. - P. 353-370.

20. Schleiermacher, F. Wie sehr es die Würde des Menschen erhöht, wenn er mit ganzer Seele an der bürgerlichen Vereinigung hängt, der er angehört /F. Schleiermacher // Friedrich Schleiermacher's sämmtliche Werke. Zweite Abtheilung. Predigten. Band 1. - Berlin : Verlag G. Reimer, 1834. - P. 218-233.

21. Schulze, J. F. Am 24sten August 1809 bei der Einsetzung des neuen Magistrats zu Fürstenwalde gehalten / J. F. Schulze // Gemeinnütziges Magazin für Prediger auf dem Lande und in kleinen Städten. 1810. - № 4 (2). - P. 75-88.

22. Schulze, J. F. Rede am Wahltage der Stadtverordneten im Jahre 1810 / J. F. Schulze // Gemeinnütziges Magazin für Prediger auf dem Lande und in kleinen Städten. - 1812. - № 6 (2). - P. 59-69.

23. Schulze, J. F. Vor der Wahl der Stadtverordneten zu Fürstenwalde gehalten am Sonntage Oculi 1809 / J. F. Schulze // Gemeinnütziges Magazin für Prediger auf dem Lande und in kleinen Städten. - 1810. - № 4 (2). - P. 62-74.

24. Stamm-Kuhlmann, T. War Friedrich Wilhelm III. von Preußen ein Bürgerkönig? / T. Stamm-Kuhlmann // Zeitschrift für Historische Forschung. - 1989. № 16 (4). - P. 441-460.

25. Tiede, T. Die Freiheit der Unterthanen: Eine Predigt am Palm-Sonntage 1809 gehalten zu Reichenbach / T. Tiede. - Reichenbach : Müller, 1809. -8 p.

26. Tiede, T. Ein Wort an Reichenbachs Bürger den 13ten Februar 1809 / T. Tiede // Gemeinnütziges Magazin für Prediger auf dem Lande und in kleinen Städten. - 1810. - № 4 (2). - P. 104-114.

27. Triest, J. Bürgersinn. In einer am 5. März 1809 auf Veranlassung der Stettinschen Bürgerwahlen gehaltenen Predigt dargestellt / J. Triest. - Stettin : Verlag Johann Samuel Leich, 1809. - 38 p.

28. Tscheggey, S. G. Warum besonders jetzt unserm Volke der Sinn für das Heilige und Unsichtbare zu wünschen wäre? Eine Predigt am 23sten Sonntage nach Trinit. 1808 gehalten zu Freystadt / S. G. Tscheggey // Neues Archiv für Prediger. Oder Bemerkungen und Materialien für den christlichen Religions-Lehrer in allen seinen AmtsVerhältnissen. - 1809. - № 2 (2). - P. 80-96.

29. Wegener, W. G. Altar-Rede vor der Vereidigung des Magistrats zu Züllichau am 20. 
October 1809 / W. G. Wegener // Gemeinnütziges Magazin für Prediger auf dem Lande und in kleinen Städten. - 1810. - № 4 (2). - P. 53-62.

30. Zwei Reden vor der anzustellenden Wahl der Stadtverordneten und ihrer Stellvertreter in der französischen Werderschen Kirche von Herrn Prediger und Professor Palmié deutsch gehalten, den 18ten und 21sten April 1809 // Gemeinnütziges Magazin für Prediger auf dem Lande und in kleinen Städten. 1810. - № 4 (1). - P. 65-78.

\section{REFERENCES}

1. Botzenhart M. Reform, Restauration, Krise. Deutschland 1789-1847. Frankfrurt-am-Main, Suhrkamp Verlag, 1985. $171 \mathrm{p}$.

2. Cancik P. "Einerwirksamern Theilnahme der Bürgerschaft...” Partizipationskonzepte zu Beginn des 19. Jahrhunderts. Büchner C., Musil A., eds. Die Stadtverordnetenversammlung von Potsdam im Wandel der Zeit. Potsdam, Universitätsverlag Potsdam, 2010, pp. 19-37.

3. Dapp R. Am 1. Adventssonntage 1808. Gemeinnütziges Magazin für Prediger auf dem Lande und in kleinen Städten, 1809, no. 3 (3), pp. 41-48.

4. Eylert R.F. Einreligiöser Sinn muß zu Hülfe kommen, wenn den Gesetzen des Staates von den Unterthaneneinvolles Genügegeschehensoll. Die Gedächtnißfeyer der verewigten KöniginLuise von Preußen. Berlin, Georg Decker, 1812, pp. 397-416.

5. Eylert R.F. Wiewollenwirunseren Königempfangen? Die weise Benutzung des Unglücks. Predigten, gehalten im Jahre 1809 und 1810. Berlin, Carl Friedrich Amelang, 1810, pp. 47-62.

6. Fox J. A World Survey of Religion and the State. Cambridge, Cambridge University Press, 2008. 206 p. DOI: https://doi.org/10.1017/CBO978051199303.

7. Hagemann K. Nation, Krieg und Geschlechterordnung. Zumkulturellen und politischen Diskurs in der Zeit der antinapoleonischen Erhebung Preußens 1805-1815. Geschichte und Gesellschaft. Zeitschrift für historische Sozialwissenschaft, 1996, no. 22 (4), pp. 562-591.

8. Heger A. Evangelische Verkündigung und deutsches Nationalbewusstsein. Zur Geschichte der Predigt von 1806-1848. Berlin, Junker und Dünnhaupt Verlag, 1939. 280 p.

9. Hintze O. Die Epochen des evangelischen Kirchenregiments in Preußen. Historische Zeitschrift, 1906, no. 97 (1), pp. 67-118.

10. Lehmann M. Der Ursprung der Städteordnung von 1808. Preußische Jahrbücher, 1898, no. 93, pp. 471-514.

11. Mieck I. Die verschlungenen Wege der Städtereform in Preußen (1806-1856). Sösemann B.,
Hrsg. Gemeingeist und Bürgersinn. Die preußischen Reformen. Berlin, Duncker\&Humblot, 1993, pp. 53-83.

12. Münchow-Pohl B. Zwischen Reform und Krieg. Untersuchungenzur Bewußtseinlage in Preußen 1809-1812. Göttingen, Vandenhoeck \& Ruprecht, 1987.479 p.

13. Neumann J. Predigtam 23. Jul. 1809. vor der feierlichen Einsetzung des neuen Magistratszu AltLandsberg. Gemeinnütziges Magazin für Prediger auf dem Lande und in kleinen Städten, 1810, no. 4 (2), pp. 88-103.

14. Neumann J. Predigt bei wiederholter Wahl der Stadtverordneten in Alt-Landsberg 1810. Magazin für Prediger auf dem Lande und in kleinen Städten, 1811, no. 5 (3), pp. 57-67.

15. Neumann J. Predigtbey Gelegenheit der Allerhöchst anbefohlenen neuen Städteordnung vor der Wahl der Stadtverordneten in Alt-Landsberg gehaltenam 20sten März 1809. Berlin, Dieterici, 1809. 16 p.

16. Nipperdey T. Deutsche Geschichte 18001866. Bürgerwelt und starker Staat. München, Verlag C.H. Beck, 1983. 838 p.

17. Oberschelp R. Politische Predigten 17271866. Niedersächsische Beispieleaus Krieg und Frieden. Hildesheim, Verlag August Lax, 1985. 224 p.

18. Schleiermacher F. Ueber das rechte Verhältniß des Christen zu seiner Obrigkeit. Im Januar 1809. Friedrich Schleiermachers sämmtliche Werke. Zweite Abtheilung. Predigten. Band 4. Berlin, Verlag G. Reimer, 1835, pp. 1-13.

19. Schleiermacher F. Ueber die rechte Verehrung gegen das einheimische große auseinerfrüheren Zeit. Am vierundzwanzigsten Jenner 1808. Friedrich Schleiermachers sämmtliche Werke. Zweite Abtheilung. Predigten. Band 1. Berlin, Verlag G. Reimer, 1834, pp. 353-370.

20. Schleiermacher F. Wiesehres die Würde des Menschen erhöht, wennermitganzer Seelean der bürgerlichen Vereinigung hängt, der erangehört. Friedrich Schleiermachers sämmtliche Werke. Zweite Abtheilung. Predigten. Band 1. Berlin, Verlag G. Reimer, 1834, pp. 218-233.

21. Schulze J.F. Am 24sten August 1809 bei der Einsetzung des neuen Magistrats zu Fürstenwalde gehalten. Gemeinnütziges Magazin für Prediger auf dem Lande und in kleinen Städten, 1810, no. 4 (2), pp. 75-88.

22. Schulze J.F. Redeam Wahltage der Stadtverordneten im Jahre 1810. Gemeinnütziges Magazin für Prediger auf dem Lande und in kleinen Städten, 1812, no. 6(2), pp. 59-69.

23. Schulze J.F. Vor der Wahl der Stadtverordneten zu Fürstenwalde gehalten am Sonntage Oculi 1809. Gemeinnütziges Magazin für Prediger auf dem Lande und in kleinen Städten, 1810, no. 4 (2), pp. 62-74. 
24. Stamm-Kuhlmann T. War Friedrich Wilhelm III. Von Preußen ein Bürgerkönig? Zeitschrift für Historische Forschung, 1989, no. 16 (4), pp. 441-460.

25. Tiede T. Die Freiheit der Unterthanen: Eine Predigtam Palm-Sonntage 1809 gehalten zu Reichenbach. Reichenbach, Müller, 1809.8 p.

26. Tiede T. Ein Wort an Reichenbachs Bürger den 13ten Februar 1809. Gemeinnütziges Magazin für Prediger auf dem Lande und in kleinen Städten, 1810, no. 4(2), pp. 104-114.

27. Triest J. Bürgersinn. In eineram 5. März 1809 auf Veranlassung der Stettinschen Bürgerwahlen gehaltenen Predigt dargestellt. Stettin, Verlag Johann Samuel Leich, 1809. 38 p.

28. Tscheggey S.G. Warum besonders jetzt unserm Volke der Sinn für das Heilige und Unsichtbarezu wünschen wäre? Eine Predigtam 23sten Sonntagenach Trinit. 1808 gehalten zu Freystadt. Neues Archiv für Prediger. Oder Bemerkungen und Materialien für den christlichen Religions-Lehrer in allenseinen AmtsVerhältnissen, 1809, no. 2 (2), pp. 80-96.

29. Wegener W.G. Altar-Redevor der Vereidigung des Magistratszu Züllichau am 20. October 1809. Gemeinnütziges Magazin für Prediger auf dem Lande und in kleinen Städten, 1810, no. 4 (2), pp. 53-62.

30. Zwei Redenvor der anzustellenden Wahl der Stadtverordneten und ihrer Stellvertreter in der französischen Werderschen Kirche von Herrn Prediger und Professor Palmiédeutschgehalten, den 18ten und 21 sten April 1809. Gemeinnütziges Magazin für Prediger auf dem Lande und in kleinen Städten, 1810, no. 4 (1), pp. 65-78.

\section{Information About the Author}

Dmitrii V. Sterkhov, Candidate of Sciences (History), Associate Professor, Department of History of Medicine and Social and Humanitarian Studies, Pirogov Russian National Research Medical University, Ostrovityanova St, 1, 117997 Moscow, Russian Federation, enkiddu@mail.ru, https://orcid.org/0000-0003-3173-793X

\section{Информация об авторе}

Дмитрий Владимирович Стерхов, кандидат исторических наук, доцент кафедры истории медицины и социально-гуманитарных наук, Российский национальный исследовательский медицинский университет им. Н.И. Пирогова, ул. Островитянова, 1, 117997 г. Москва, Российская Федерация, enkiddu@mail.ru, https://orcid.org/0000-0003-3173-793X 